\title{
MICROBIOLOGICAL EVALUATION OF RAW, PASTEURIZED MILK AND ZABADI BALADI AFTER FENNEL HONEY TREATMENT
}

\author{
WALAA M.A. ELSHERIF and NAHED M. WAHBA
}

Animal Health Research Institute, Assiut Regional Laboratory.

\section{ABSTRACT}

Received at: $29 / 9 / 2012$

Accepted: 22/10/2012
The primary purpose of this research was to monitor the influence of fennel honey addition to raw, pasteurized milk and Zabadi baladi on survival of the microbial flora during refrigerated storage in order to expend their viability date. Results showed that addition of honey at concentrations of $0,1 \%, 5 \%$ and $10 \%$ affects the Staph. organisms count and total colony count during storage at $4{ }^{\circ} \mathrm{C}$ in all trails with specific effect of honey at $10 \%$. However, it did not significantly influence on shelf life time of samples and on the yeast and mold count. Similarly, honey affects on $\mathrm{pH}$ and lactic acid levels of samples. Raw, pasteurized milk and Zabadi baladi prepared with $1 \%$ and $5 \%$ Fennel honey were acceptable to the consumer and considered the most preferable type. Despite these findings, enrichment of raw, pasteurized milk and Zabadi baladi with honey is recommended because honey is a natural sweetener that possesses a wide range of beneficial nutritional properties.

Key words: Pasteurized milk, Raw milk, Zabadi baladi and Fennel honey.

\section{INTRODUCTION}

Milk is an important natural food and it exceeds all other foods in the variety and quality of contents with which milk furnishes the human body at all stages of life. So, Prophet Mohamed each time drinks milk calls to Allah to bless milk and to be increased more than other foods.

High quality raw milk free from pathogenic microorganisms, with less than 50,000 microorganisms $/ \mathrm{ml}$ is a growing concern worldwide by the public health authorities, milk industries and consumers due to firstly, the production of high quality dairy products secondly to reduce the significant increase in the incidence of milkborne illnesses (Desmasures et al., 1997).

Zabadi baladi is the most popular fermented milk produced in Egypt. The great popularity of Zabadi baladi is due to its refreshing and thirst-quenching in hot weather especially in Assuit, Egypt. The value of yoghurt in human nutrition is based not only on the strict nutritive effect of milk from which it is made and increased digestibility due to changes of milk constituents during the fermentation period, but also on the beneficial effect of intestinal micro flora, prophylactic and healing effects (Hussein and Kebary, 1999 and Zedan et al., 2001).

Likewise, honey natural food product produced by honey bees its usage since ancient time's Major use in ayurveda, cosmetics and food products (Archana, 2010). The bees were quoted by Surat in the Holy Qur'an "There are issues from within their bodies a drink of varying colors, wherein is healing for men, verily in this is a sign for those who give thought" (Marmaduke, 1981). In recent years, there has been increasing interest in the use of natural food additives and incorporation of health-promoting substances into the diet. Honey, which is a natural syrup containing primarily fructose $(38.4 \%)$ and glucose $(30.3 \%)$, has been gaining interest as a substitute sweetener in various foods because of its healthy image (Chick et al., 2001 and Ustunol and Gandhi, 2001). Its low pH of approximately 3.9 makes honey compatible with many food products in terms of acidity. Factors in honey contributing to its antibacterial nature have clearly not been fully understood (Taormina et al., 2001). These may include the high sugar content, which limits the amount of water available to microorganisms for growth, the relatively high acidity, the presence of organic acids, and the presence at low concentrations of hydrogen peroxide (Mundo et al., 2004). However, it is worth noting that, depending on floral sources of the honey, its antimicrobial characteristics reportedly vary (Molan, 1992).

In the present study, an attempt has been made to study the antibacterial property of honey and its applicability as a natural preservative of raw, pasteurized milk and Zabadi baladi samples. 


\section{MATERIALS and METHODS}

\section{1- Collection and Preparation of samples:} (Krushna et al., 2007)

Raw milk and Zabadi baladi samples were obtained from dairy shops in Assuit City, Egypt while, pasteurized milk samples (flash method pasteurization) were obtained from the pasteurization unit in Assiut University.

Each sample divided into four parts and fennel honey was added at concentrations of 0 (honey free), 1, 5 and $10 \%$. Control samples examined immediately. 3 trials of each experiment were carried out. The samples were stored at refrigeration temp. at $5 \pm 2{ }^{\circ} \mathrm{C}$ and examined daily until the signs of deterioration of the products.

\section{2- Microbiological evaluation:-}

Each sample from milk and milk products was subjected to the following tests:

- Total bacterial count using Standard plate count media and incubation at $37^{\circ} \mathrm{C}$ for 48 h. (A.P.H.A., 1992)

- Staph. count using Paird parker media $\left(37^{\circ} \mathrm{C}\right.$ for 24-48h) (ICMSF, 1978)

- Yeast and mold count using Malt extract agar $\left(26^{\circ} \mathrm{C}\right.$ for 5-7days) (Harrigan and Mc Cance, 1976).

\section{3- Validation tests:-}

* Clot on boiling test: (Harvey and Hill, 1951)

$3 \mathrm{ml}$ of the milk sample were transferred into a sterile test tube and placed in a boiling water bath for $5 \mathrm{~min}$.
The level of the water in the bath should be above that of the milk in the tube. Clotting of milk indicates souring of milk.

\section{* Acidity test: (A.O.A.C., 1975)}

Milk: - equal amount of milk and distilled water (10 $\mathrm{ml}$ ) were used and then $1 \mathrm{ml} \mathrm{ph}$. ph. added as indicator. The first persistence of faint pink color considered the end point. Acidity \% was calculated as Reading /10. (Normal acidity of milk is 0.12$0.16 \%$ with average $0.14 \%$ ).

Zabadi baladi:- In a beaker $10 \mathrm{~g}$ from prepared Zabadi, $20 \mathrm{ml}$ distilled water and $1 \mathrm{ml} \mathrm{ph}$. Ph. (alcoholic solution) were add and titrated against $\mathrm{N} / 10 \mathrm{NaOH}$ till appearance of faint pink color. Acidity \% was calculated as Reading /10. (Normal acidity of Zabadi baladi is $0.7-0.8 \%$ ).

* PH value: (A.P.H.A., 1992)

It was detected by using electrical digital $\mathrm{pH}$ meter (an Orion Model).

\section{4- Sensory evaluation:-}

Pasteurized milk and Zabadi baladi were prepared as previously mentioned and each was subjected to the previous treatments. Thirty consumers were selected in teams of different ages, sex (20 females and 10 males), and education to taste the trials. The perception of consumers toward samples with various conc. of fennel honey was studied with respect to two different attributes (flavor and palatability). The level of agreement was scored as strongly agree (SA), agree (A), disagree (D), and strongly disagree (SD) according to Nelson and Torut (1981).

\section{RESULTS}

The results were summarized in Tables 1-3 and Figures 1-4.

Table 1: Average $\mathrm{pH}$ and acidity $\%$ of raw milk samples.

\begin{tabular}{ccccc}
\hline Type & $0 \%$ (honey free) & $1 \%$ honey & $5 \%$ honey & $10 \%$ honey \\
\hline $\mathrm{pH}$ & 6.3 & 5.3 & 5.1 & 4.93 \\
\hline Acidity\% & 0.16 & 0.37 & 0.47 & 0.83 \\
\hline
\end{tabular}

Table 2: Average $\mathrm{pH}$ and acidity $\%$ in Zabadi baladi.

\begin{tabular}{cccccc}
\hline Type & Days of storage & 0\%(honey free) & 1\% honey & $5 \%$ honey & $10 \%$ honey \\
\hline \multirow{2}{*}{$\mathrm{pH}$} & 1st day & 3.7 & 2.93 & 2.93 & 2.8 \\
\cline { 2 - 6 } & 2nd day & 3.17 & 2.87 & 2.11 & 2.7 \\
\hline \multirow{2}{*}{ Acidity\% } & 1st day & 1.27 & 2.07 & 2.17 & 2.27 \\
\cline { 2 - 6 } & 2nd day & 1.73 & 1.93 & 2.00 & 2.03 \\
\hline
\end{tabular}


$\underline{\text { Assiut Vet. Med. J. Vol. } 58 \text { No. } 135 \text { October } 2012}$

Table 3:- Average $\mathrm{pH}$ and acidity $\%$ in pasteurized milk.

\begin{tabular}{cccccc}
\hline Type & Days of storage & 0\%(honey free) & $1 \%$ honey & $5 \%$ honey & $10 \%$ honey \\
\hline \multirow{2}{*}{$\mathrm{pH}$} & 1st day & 5.9 & 5.3 & 5 & 5 \\
\cline { 2 - 6 } & 2nd day & 5.7 & 5.7 & 5 & 5 \\
\cline { 2 - 6 } & 3rd day & 5.2 & 5.0 & 4.9 & 4.9 \\
\hline \multirow{2}{*}{ Acidity \% } & 1st day & 0.23 & 0.46 & 1.0 & 0.8 \\
\cline { 2 - 6 } & 2nd day & 0.36 & 1.00 & 1.3 & 1.4 \\
\cline { 2 - 6 } & 3rd day & 0.70 & 1.00 & 1.0 & 1.0 \\
\hline
\end{tabular}

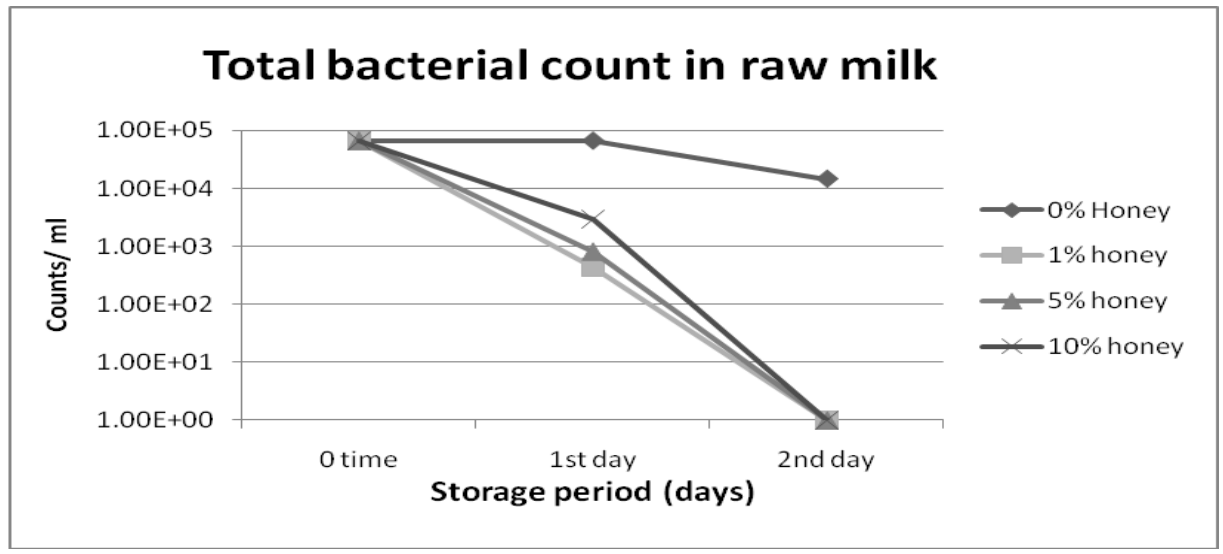

Fig. 1 A: Effect of Fennel honey on Total bacterial count in raw milk.

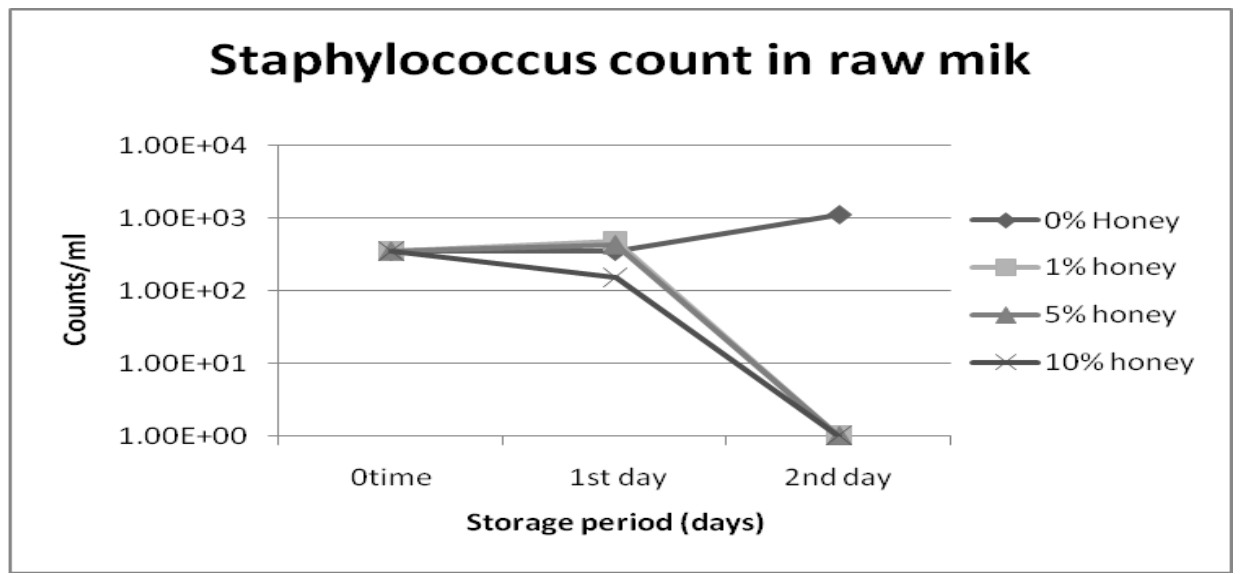

Fig. 1 B: Effect of Fennel honey on Staphylococcus count in raw milk.

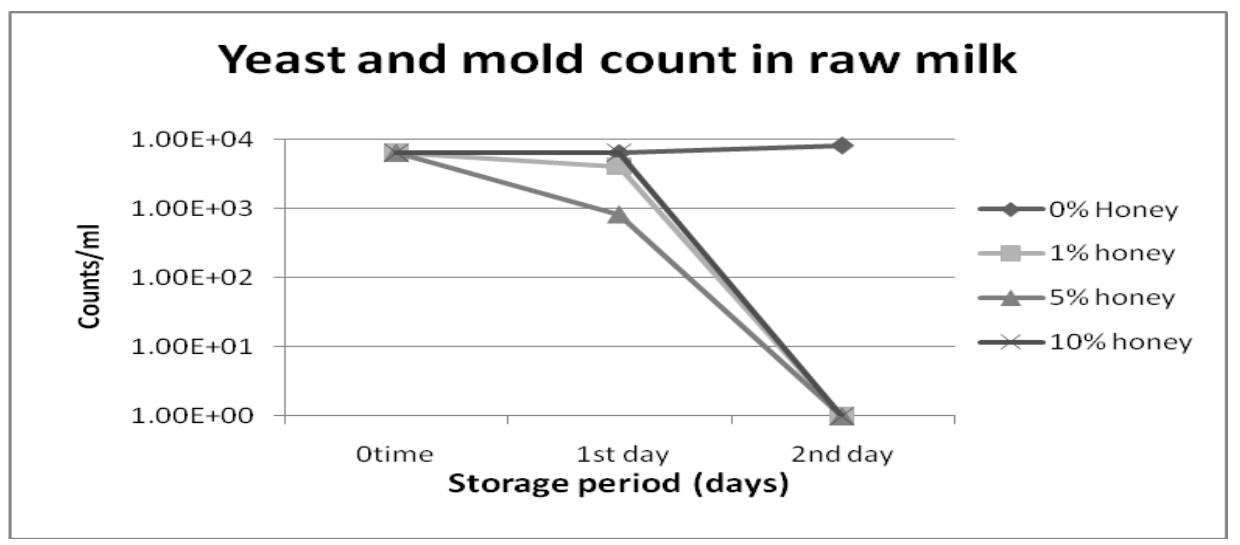

Fig. 1 C: Effect of Fennel honey on Yeast and mold count in raw milk. 


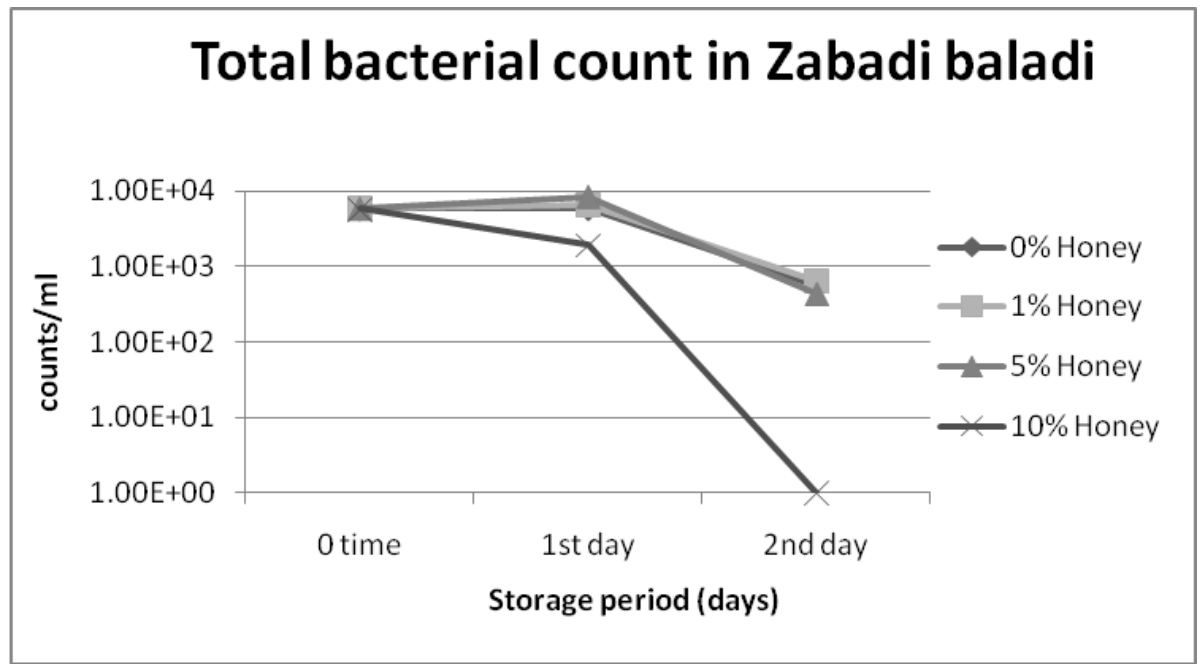

Fig. 2 A: Effect of Fennel honey on Total bacterial count in Zabadi baladi.

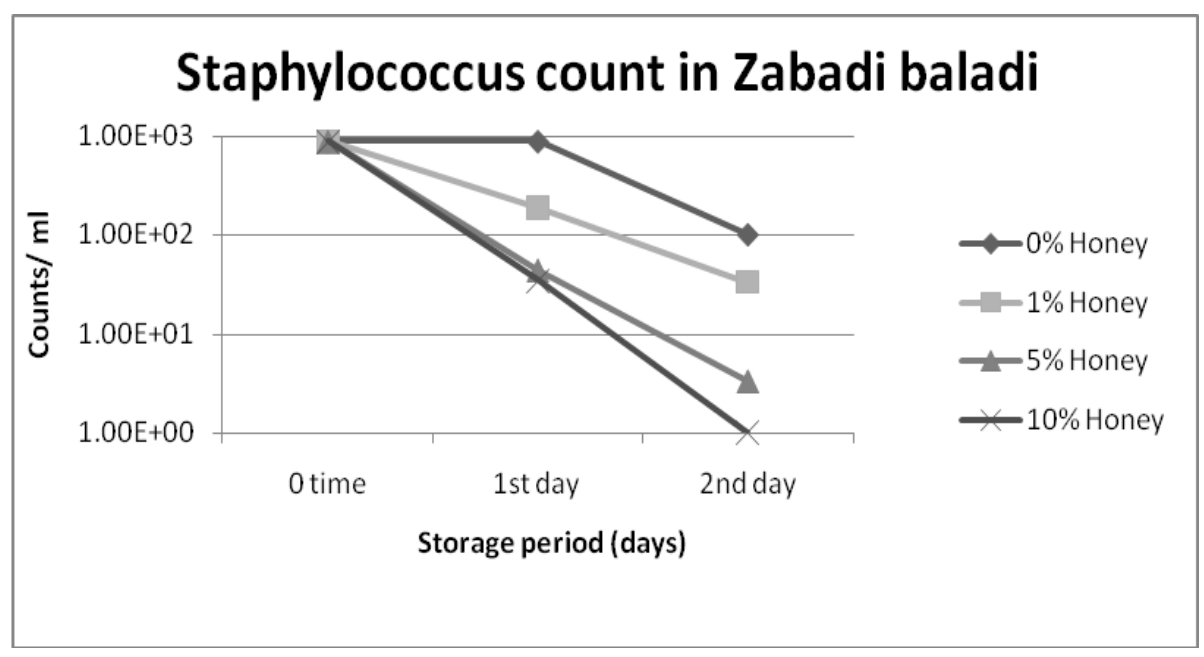

Fig. 2B: Effect of Fennel honey on Staphylococcus count in Zabadi baladi.

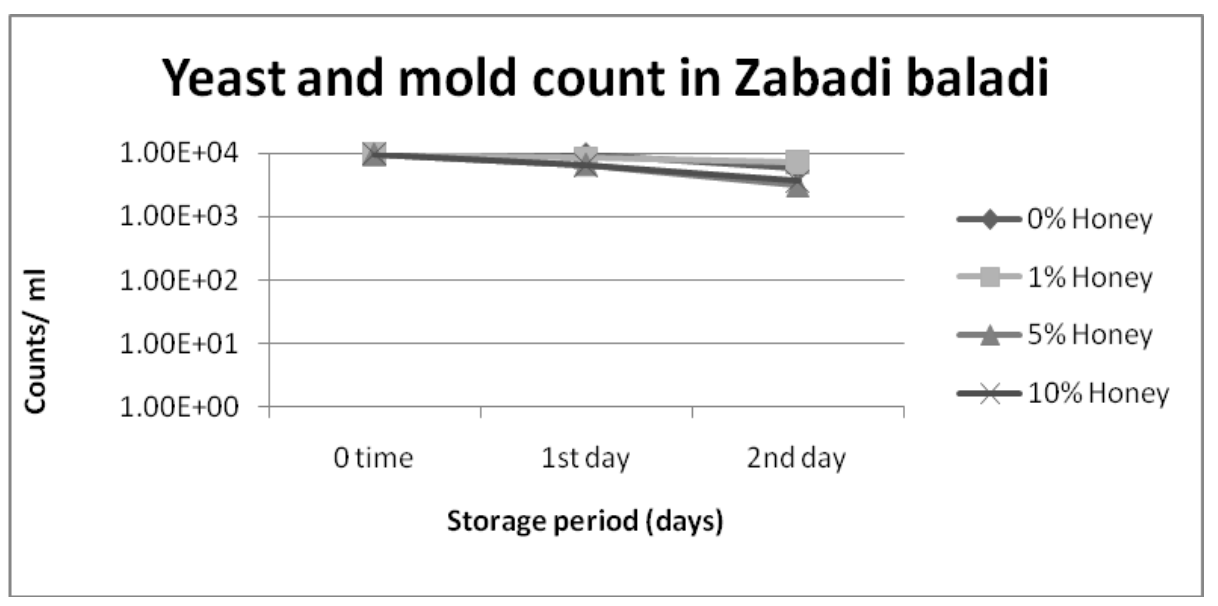

Fig. 2C: Effect of Fennel honey on Yeast and mold count in Zabadi baladi. 


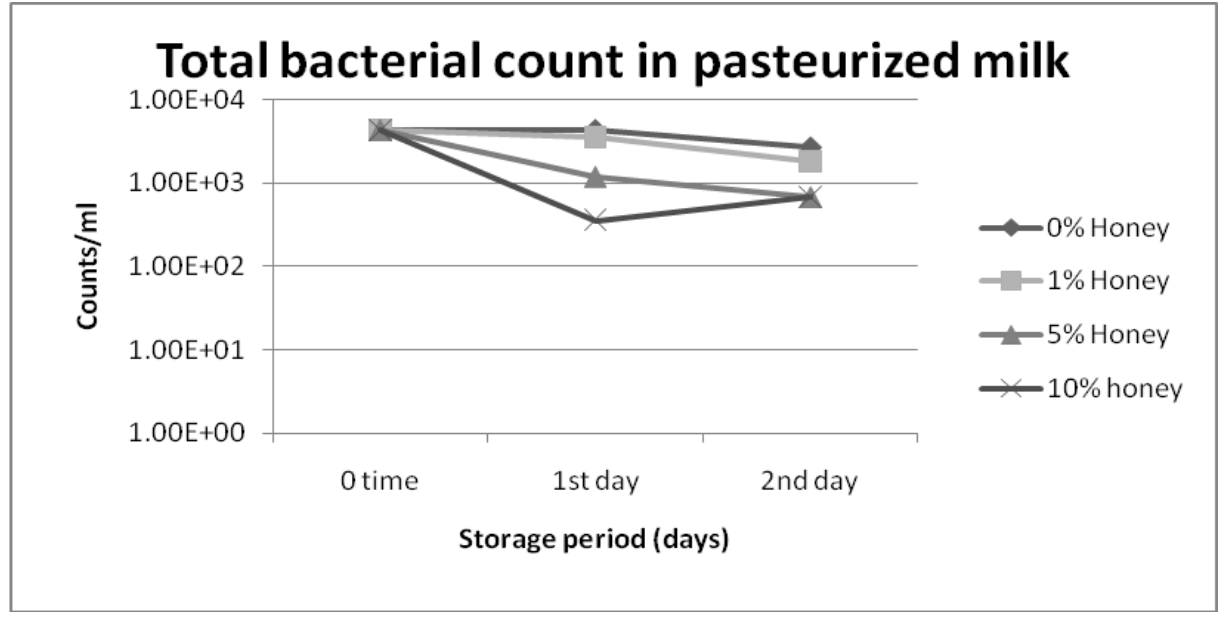

Fig. 3A: Effect of Fennel honey on Total bacterial count in pasteurized milk.

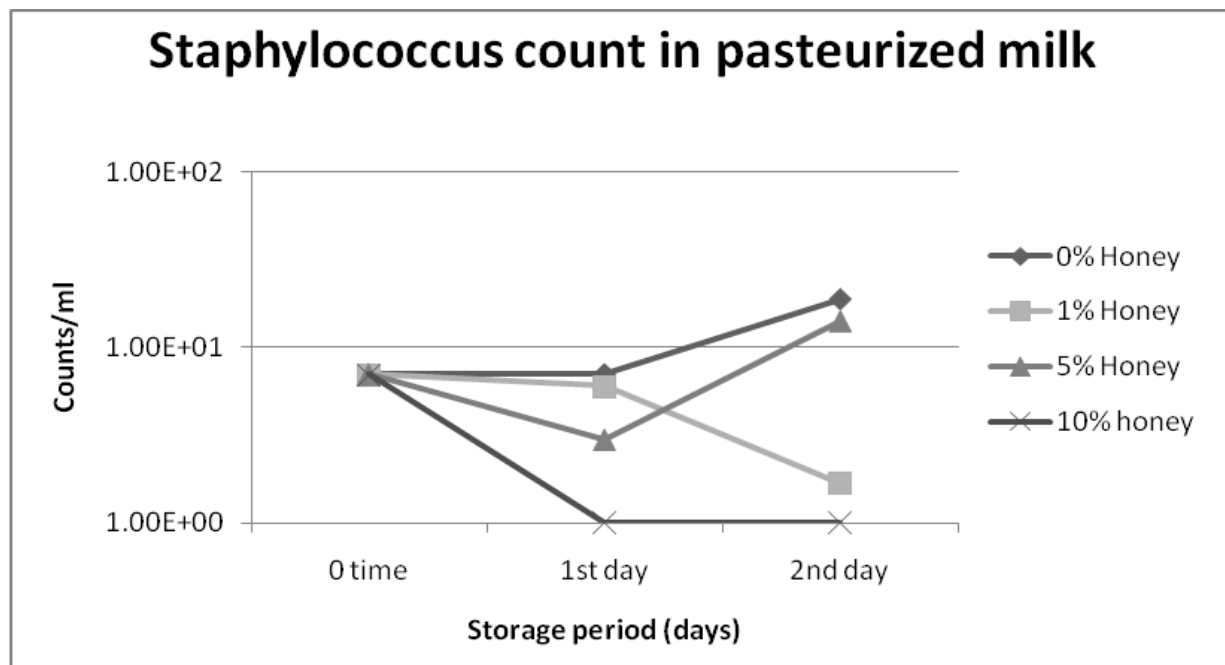

Fig. 3 B: Effect of Fennel honey on Staphylococcus count in pasteurized milk.

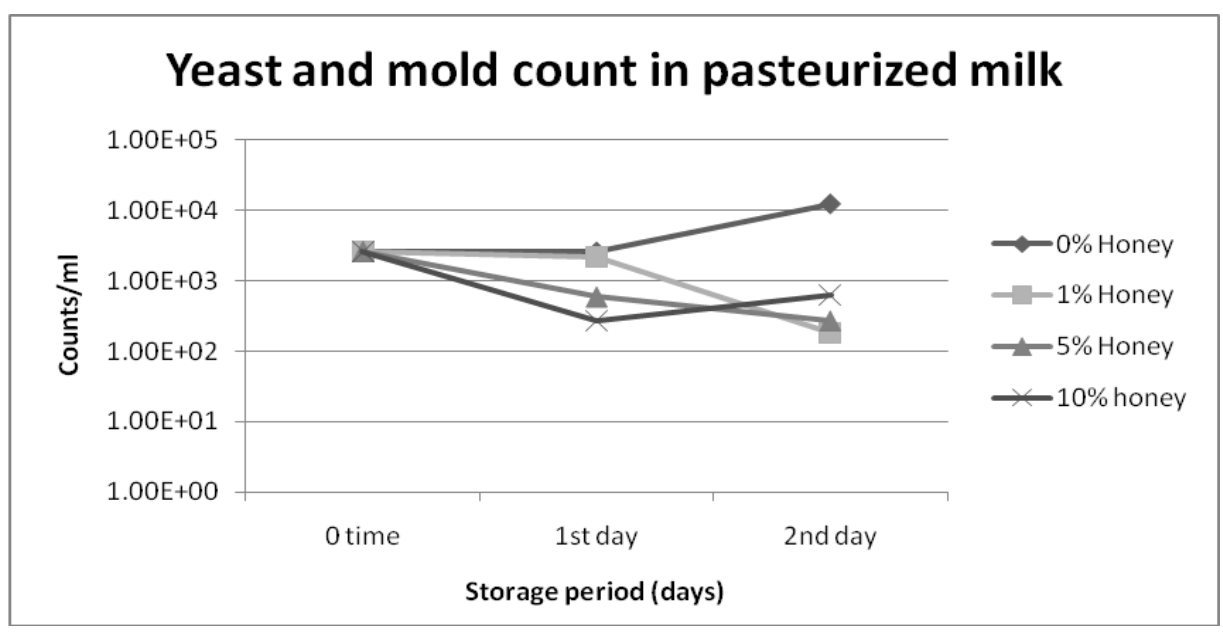

Fig. 3 C: Effect of Fennel honey on Yeast and mold count in pasteurized milk. 


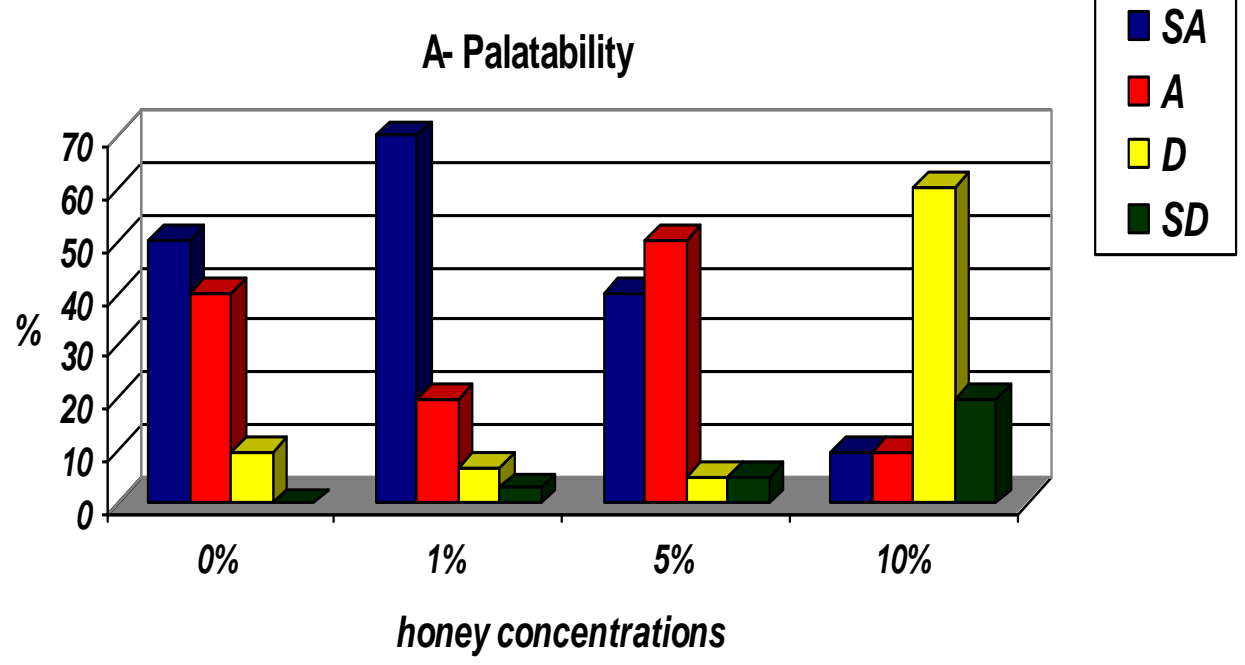

Fig. 4A:- Level of agreement of consumer acceptability to palatability of different honey concentrations.

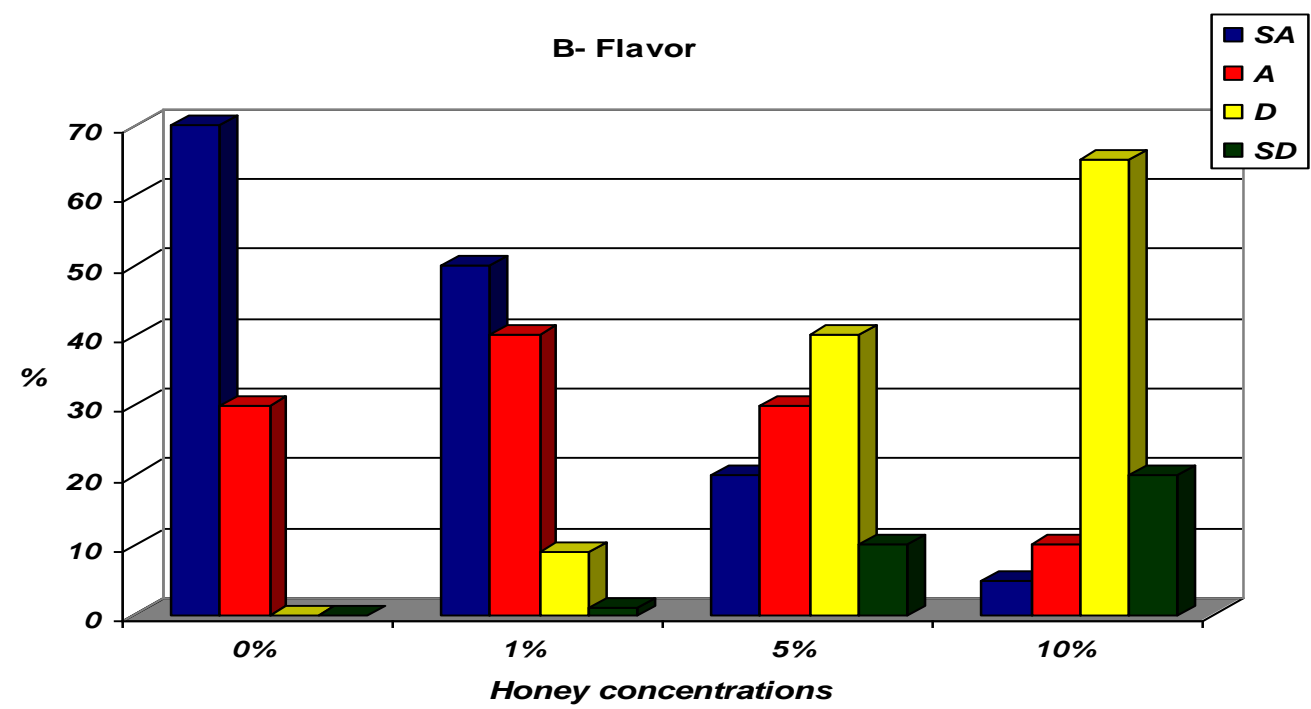

Fig. 4B:- Level of agreement of consumer acceptability to flavor of different honey concentrations.

Strongly Agree (SA), Agree (A), Disagree (D) and Strongly Disagree (SD)

\section{DISCUSSION}

Milk from various sources has been used as food since pre-historic times. Although much of it is consumed with minimal processing, highly processed milk products and components find usage in several foods. The preservation of milk in the developing countries presents a problem in that, the ambient temperatures tend to be high with limited refrigeration facilities (Krushna et al., 2007). So, this study tried to evaluate addition of honey as a new method for preservation of milk. The results of raw milk samples showed decrease in average count of total bacterial count (TBC), yeast and mold and
Staph.organisms with the increase of Fennel honey concentrations so they could not be detected in the second day (Fig.1A, B and C). It may be due to the increase of acidity percent in all trials especially with $10 \%$ fennel honey concentration (Table 1).

Various additives of non dairy origin are used in the manufacture of milk products because of their beneficial contribution to the sensory, therapeutic, or other properties of dairy foods (Molnár et al., 2005). In this study Fennel honey was added to Zabadi baladi to improve microbiological condition and increase shelf life of the product. The results indicated decrease in TBC, Staph.organisms in all 
trials and they could not be detected in the second day by addition of $10 \%$ fennel honey, this may be referred to increase the acidity percent with increase the conc. of honey (Fig. 2A, B, C and Table 2). Rashid and Thakur (2012) reported that the $\mathrm{pH}$ value goes on decreasing with increase the percentage of honey. This might be due to increase in acidity, as acidity and $\mathrm{pH}$ are inversely proportional to each other. On the other hand, enrichment of yogurt with honey is recommended because honey is a natural sweetener that possesses a wide range of beneficial nutritional properties (László, 2006).

The antimicrobial activity of honeys against several bacterial species known to cause spoilage of food has been found to be variable (Allen et al., 1991). Regarding the pasteurized milk, the total bacterial count decreased, but still detected till the second day at all honey concentrations (Fig. 3A). It may be returned to the presence of some catalase negative bacteria, thermophilic and spore former organisms which considered more resistant to high concentration of honey (Taormina et al., 2001) or Gram negative bacteria as honey has little effect on it (Ali et al., 2005). Fig. 3B showed that failed detection Staph.organisms in pasteurized milk with $10 \%$ honey at the first day. Staph.organisms are the most sensitive bacterial species to honey and widely recommended to be used as a model in honey antibacterial comparative studies (Ali et al., 2005). An increase in yeast and mold count noticed in control samples at the second day, however $1 \%$ fennel honey affect on it (Fig. 3C). The majority of yeasts and molds are obligate aerobes and their acid/alkaline requirement for growth is quite broad, ranging from $\mathrm{pH} 3$ to above $\mathrm{pH} 9$ (BAM, 2001). Moreover, Fennel honey $\mathrm{pH}$ ranged (3-5) acts as inhibitory media to most pathogens that require $\mathrm{pH}$ 7.2-7.4 for their bioactivity (Molan, 1992 and Ali et al., 2005). Likewise, clot on boiling test for raw milk indicated that samples expired at third day may be due to the increased acidity with addition of honey (Table 3).

The antibacterial activity of honey has been attributed both to physical factors: osmolority, acidity and chemical factors such as hydrogen-peroxide, volatiles, propolis and unidentified substances from certain floral source (Selcuk and Nevin, 2001).

The ability of honey to kill microorganisms has been attributed to its high osmotic effect due to high sugar concentration of honey, high acidic nature ( $\mathrm{pH}$ being 3.2-4.5), glucose oxidase produces the antibacterial agent like hydrogen peroxide and other non-peroxide antibacterial substances with different phytochemical origin, e.g. aromatic acids and also compounds of different chemical properties, phenolics and flavonoids, i.e. its content of tetracycline derivatives, peroxides, amylase, fatty acids, phenols, ascorbic acid, flavonides, streptomycin, sulfathiazole, trepens, benzyl alcohol, and benzoic acids. The term "oxidative stress" describes the lack of equilibrium in the organisms between the production of free radicals and the antioxidant protective activity. The protection against oxidation is thought to prevent some chronic diseases like tuberculosis. However, the production and type of honey produced by honeybees is dependent on the natural vegetative flowers blooming in different seasons. Thus, the flowers from which bees gathered nectar to produce the honey may contribute to the difference in the antimicrobial activities of honey (Heerng et al., 1998; Stefan, 2009; Christy et al., 2010 and Rashid and Thakur, 2012).

Regarding, the perception of consumers toward samples subjected to various honey conc. with respect to two different attributes (flavor and palatability), $70 \%$ of consumers were strongly agree to addition of $1 \%$ honey and $40 \%$ of consumers to $5 \%$ honey (Fig. 4 $\mathrm{A}$ and $\mathrm{B}$ ). Generally, $1 \%$ and $5 \%$ fennel honey conc. considered the most preferable additives in all samples than $10 \%$ fennel honey conc.

\section{CONCLUSION}

It could be concluded that addition of honey at concentration of $0,1 \%, 5 \%$ and $10 \%$ affects the Staph.organisms counts and total colony counts during storage at $4{ }^{\circ} \mathrm{C}$ in all trails with specific effect of honey at $10 \%$. However, it did not significantly influence on shelf life time of samples and on the yeast and mold counts. $1 \%$ and $5 \%$ fennel honey conc. considered the most preferable additives in all samples.

\section{REFERENCES}

A.O.A.C. (1975): Assocition of Official Agricultural Chemist, Official Methods of Analysis. http://www.qclscientific.com/PDFs/Applicatio n\%20Notes/026A-FD\%20Titration\%20$\% 20$ Acidity\%20of\%20Milk.pdf

A.P.H.A. (American Public Health Association) (1992): Standard methods for examination of dairy products. INC., $16^{\text {th }}$ Ed. New York.

Ali, M.M.; Wahba Nahed, M.; Abdel-Rahman, M.F. and Abdel-Hafeez, M.M. (2005): Antibacterial activity of honey for treatment of subclinical bovine mastitis: 1 - In vitro study of bacterial inhibins and chemical bioassay of some different honeys. $8^{\text {th }}$ Sci. Cong., Egyptian Society For Cattle Diseases, 11-13 Dec. 2005, Assiut, Egypt.

Allen, K.L.; Molan, P.C. and Reid, G.H. (1991): Survey of the anti-microbial activity of some New Zealand honeys, J. Pharm. Pharmacol., 43 (1991) 817.

Archana, N. (2010): Honey as a Natural Preservative in Milk.

http://www.slideshare.net/coolarchana11/hone y-as-a-natural-preservative-in-milk. 
B.A.M. (2001): Yeasts, Molds and Mycotoxins. Bacteriological Analytical Manual. Ch. 18. Yeasts, Molds and Mycotoxins. http://www. fda. Gov/ Food/ Science Research/ LaboratoryMethods/BacteriologicalAnalytical ManualBAM/ucm071435.htm.

Chick, H.; Shin, H.S. and Ustunol, Z. (2001): Growth and acid production by lactic acid bacteria and bifidobacteria grown in skim milk containing honey. Food Science., 66: 478-481.

Christy, E.M.; Anna, M.C.; Thilivhali, M.; Ezekiel, G.; Noxolo, F.M. and Roland, N.N. (2010): Selected South African honeys and their extracts possess in vitro anti-helicobacter pylori activity. Arch. Med. Res., 41: 324-331.

Desmasures, N.; Bazin, F. and Gueguen, M. (1997): Microbiological composition of raw milk from selected farms in the Camembert region of Normandy. J. Applied Microbiol., 83: 53-58.

Harrigan, W.F. and Mc Cance, E. (1976): Laboratory Methods in Food and Dairy Microbiol. Academic Press. In London Ltd.

Harvey, W.C. and Hill, H. (1951): Milk Production and Control. 3rd Ed., London U.K. Lewis and Co. Ltd. Pp. 527.

Heerng, W.; Usleber, E.; Dietrich, $R$. and Märtlbauer, E. (1998): Immunochemical screening for antimicrobial drug residue in commercial honey. Analyst, 123 (12): 27592762.

Hussein, S.A. and Kebary, K.M. (1999): Improving viability of bifidobacteria by microentrapment and their effect in stirred yoghurt. Acta Alimentaria, 28: 113.

Krushna, N.S.; Kowsalya, A.; Radha, S. and Narayanan, R.B. (2007): Honey as a natural preservative of milk. Indian J. Experimental Biology Vol. 45, May 2007, pp. 459-464.

I.C.M.S.F. (International Commission on Microbiological Specification for Foods) (1978): Microorganisms in Foods, Vol. I: Their significance and methods of enumeration $2^{\text {nd }}$ ed. Univ. Toronto Press, Toronto Buffalo, London.

László, V. (2006): Effect of acacia (Robinia pseudoacacia L.) honey on the characteristic microflora of yogurt during refrigerated storage. Varga International J. Food Microbiology 108: 272-275

Marmaduke, P.M. (1981): The meaning of the glorious Qur'an Dar Alketab Al Masri: Cairo.

Molan, P.C. (1992): The antibacterial activity of honey: 1.The nature of the antibacterial activity. Bee World, 73: 5-28.

Molnár, N.; Gyenis, B. and Varga, L. (2005): Influence of a powdered Spirulina platensis biomass on acid production of lactococci in milk. Milchwissenschaft., 60: 380-382.

Mundo, M.A.; Padilla-Zakour, O.I. and Worobo, R.W. (2004): Growth inhibition of foodborne pathogens and food spoilage organisms by select raw honeys. International J. Food Microbiology. 97: 1-8.

Nelson, J.A. and Torut, G.M. (1981): Judging Dairy Products, 4th edition revised. Westport, CT: The AVC.

Rashid, A. and Thakur, Er.S.N. (2012): Studies on quality parameters of set yoghurt prepared by the addition of honey. International $\mathrm{J}$. Scientific and Research Publications, Volume 2, Issue 9, September, 1 ISSN 2250-3153.

Selcuk, H. and Nevin, K. (2001): Investigation of antimicrobial effect of honey collected from various regions of Turkey. Apiacta., 4 (2000): $1-6$.

Stefan, B. (2009): Honey for Nutrition and Health. Book of Honey, Ch. 7, Bee Product Science, www.bee-hexagon.net.

Taormina, P.J.; Niemira, B.A. and Beuchat, L.R. (2001): Inhibitory activity of honey against foodborne pathogens as influenced by the presence of hydrogen peroxide and level of antioxidant power. International J. Food Microbiology, 69: 217-225.

Ustunol, Z. and Gandhi, H. (2001): Growth and viability of commercial Bifidobacterium spp. in honey-sweetened skim milk. Journal of Food Protection, 64: 1775-1779.

Zedan, M.A.; Zedan, A.N.; Kebary, K.M. and Mohamed, S.F. (2001): Effects of fortification of cows milk with acetylated whey protein concentrates on the quality of set yoghurt. Egyptian J. Dairy Sci., 29: 285-297.

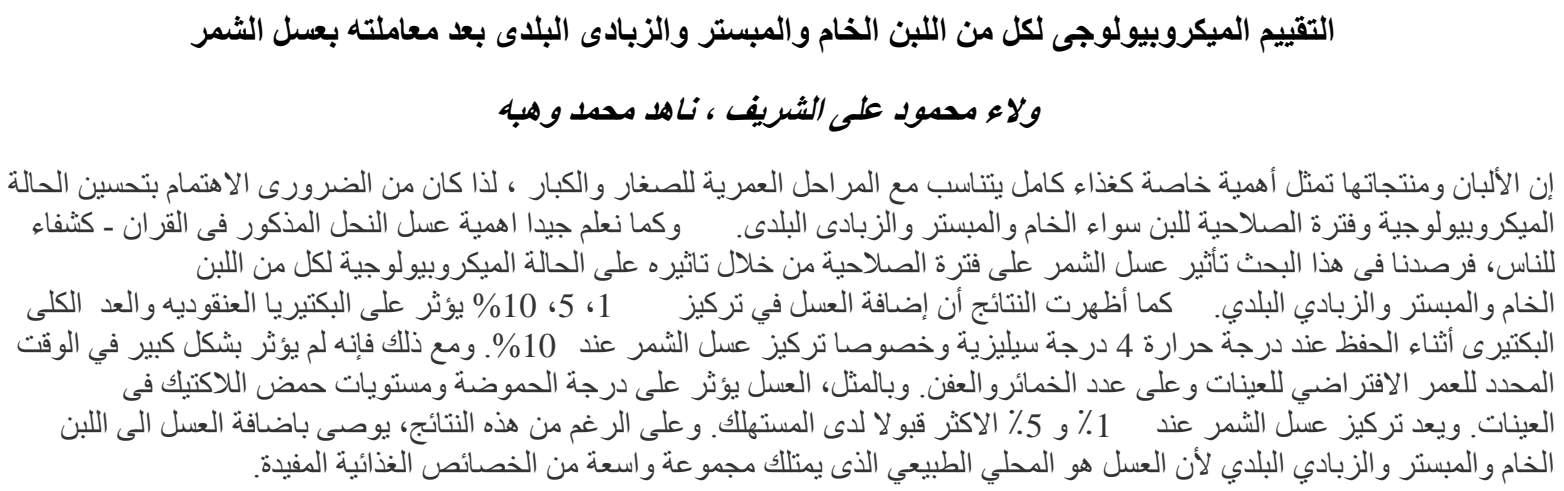

